\title{
Long-Chain Polyunsaturated Fatty Acid Concentrations in Breast Milk from Chinese Mothers: Comparison with Other Regions
}

\author{
Shi-Ying Li ${ }^{1}$, Xiao-Li Dong ${ }^{1}$, Wing-Si Vincy Wong ${ }^{1}$, Yi-Xiang Su ${ }^{1,2, *}$ and Man-Sau Wong ${ }^{1, *}$
}

${ }^{1}$ Laboratory for Infant \& Child Nutrition, Food Safety and Technology Research Centre, Department of Applied Biology and Chemical Technology, The Hong Kong Polytechnic University, Hong, Kong, People's Republic of China

${ }^{2}$ Guangdong Provincial Key Laboratory of Food, Nutrition and Health, Department of Nutrition, School of Public Health, Sun Yat-Sen University, Guangzhou 510080, People's Republic of China

\begin{abstract}
Long-chain polyunsaturated fatty acids (LC-PUFA), especially linoleic acid (LA), arachidonic acid (AA), alphalinolenic acid (ALA), eicosapentaenoic acid (EPA) and docosahexaenoic acid (DHA), are essential to infant growth and development during early life. Up till now, there is only limited number of studies with large sample size on LC-PUFA in breast milk in China. In order to better understand the LC-PUFA levels in Chinese women, we report an analysis that included 44 studies of 3815 subjects from the latest 10-year peer-reviewed papers of breast milk studies of fatty acid profiles from China and other regions: Asia (excluding China), Europe, America and Africa. The results showed that Chinese women had significantly higher LA and ALA levels in the breast milk than European and other Asian women. The DHA level in the breast milk of Chinese women meets the Chinese and international recommended intake for young infants. This review provides comprehensive investigation on the LC-PUFA levels in the mature milk of Chinese women in most recent publications and server as a reference for further studies on human milk in China.
\end{abstract}

Keywords: Human milk, long-chain polyunsaturated fatty acid, review, China, maternal diet.

\section{INTRODUCTION}

Long-chain polyunsaturated fatty acids (LC-PUFAs) are a group of polyunsaturated fatty acids (PUFA) with 18-20 or more carbons, and include the two families of the omega-3 (n-3) and omega-6 (n-6), which differ in the position of the first double bond from the methyl end group of the fatty acid [1]. Researches on the role of LC-PUFAs in early life focused on the development of the nervous system. LC-PUFAs, especially DHA and AA, accumulate richly in the central nervous system during late pregnancy through about 2 years postnatal [2]. The fast increase in brain size during the early postnatal months requires high accretion of LC-PUFAs into neural membranes [3].

LC-PUFAs are converted endogenously from the precursors ALA and LA via a series of desaturation and chain elongation steps present in the omega- 3 and omega-6 pathways; ALA is finally converted into DHA, while LA becomes AA after successive reactions in plants [4]. Mammals are unable to synthesize ALA and $L A$, and the conversion efficiency of LA and ALA into $A A, D H A$ and EPA are low; hence dietary intake of LCPUFA, which is more effective, becomes more important especially for infants [5]. ALA can be synthesized from LA in plants [4], but not in animals

*Address correspondence to this author at the Department of Applied Biology and Chemical Technology, The Hong Kong Polytechnic University, Hong Kong, People's Republic of China; Tel: +852 3400 8665; Fax: +852 2364 9932; E-mails: man-sau.wong@polyu.edu.hk, suyx@mail.sysu.edu.cn

E-ISSN: 1929-4247/15 including humans [6]. Consequently, the LA to ALAratio in diet will determine the relative amount of LC-PUFAs in the brain [7]. The value of AA to DHA proportion indicates the $n-6$ and n-3 PUFA balance desired for optimal health [8].

It is generally accepted that breast milk is the optimal choice for infant LC-PUFA supply [9]. Breast milk LC-PUFAs concentrations vary by many factors such as diet and nutritional status. Asians used to have higher intake of preformed EPA and DHA because of their tradition of regular fish and seafood consumption. However, with meat consumption surpassing fish consumption in Asia recently, decreased intake of DHA and EPA and increase in AA intake have been resulted [10]. Similarly, Chinese dietary habits have changed markedly as a result of striking economic development [11]. Until now, there is limited data review on the LCPUFA levels in Chinese breast milk. Although a systematic review on the DHA and AA concentration in human milk worldwide including China was conducted in 2007 [12], only 3 studies from Beijing were listed as representative data. More studies on Chinese human breast milk have been performed in the past 10 years. It is meaningful to review the LC-PUFA concentrations in Chinese breast milk and make a comparison with other regions including Asia, America and Africa.

Our goal is to establish the distribution of LC-PUFAs concentrations in mature breast milk from lactating mothers. Our strategy was to identify all the articles in the peer-reviewed literature that report LC-PUFA 
concentrations in the breast milk from mothers of fullterm infants. The mothers must have consumed their normal diets with no dietary intervention. We included selection criteria for data collection in the review. Summary statistics were performed between values from China and those from Asia and non-Asian regions.

\section{SUBJECTS AND METHODS}

PubMed searches were performed with the keywords "breast milk / human milk" and "fatty acid" from May to July, 2015. The papers published after January 1, 2005 were included in this study. The most recent paper was published in March 2015. China Academic Journals (CAJ) full-text database searches were also performed with the above keywords in Chinese to search publications in Chinese. The literature search is outlined in Figure 1. All data were from mothers of full-term infants in good health who consumed free-living or control diets during the intervention studies.

Breast milk is the exclusive food for breast-fed infants in their first 4-6 months of life and the WHO recommends babies should be breastfed for at least the first 6 months of their live. Thus, studies on mature human milk from 1-6 months were included in this analysis. Data from experimental groups who had special diets or consumed LC-PUFA supplements were excluded. Studies with subject number fewer than six were also excluded.

Studies meeting these criteria were split into 5 groups according to their region of investigation:
Mainland of China, Asia excluding Mainland of China, Europe, America and Africa. Fatty acids concentrations are most often reported as a percentage of the total fatty acids, by weight (wt:wt, or wt for wt). Studies that reported the fatty acid concentrations as $\mathrm{mg} / 100 \mathrm{ml}$ or mol\% without sufficient information for converting to percentage of the total fatty acids were excluded in this analysis.

All the articles analyzed in the current paper are listed in Table 1. Forty-four articles providing 65 mean values from 3815 subjects are included in this analysis.

Data are expressed as means \pm standard deviation in Tables 2 \& 3. Analyses were carried out using SPSS 12.0 for Windows. Data were analyzed by one-way ANOVA followed by post hoc Dunnett's tests to compare the mean values between the Chinese group and other groups. Differences were considered significant at $p<0.05$.

\section{RESULTS}

The linoleic acid (LA), arachidonic acid (AA), alphalinolenic acid (ALA), eicosapentaenoic acid (EPA) and docosahexaenoic acid (DHA) concentration in breast milk, as well as the ratio of AA/DHA and LA/ALA, total polyunsaturated fatty acids (PUFA), n-6 PUFA and n-3 PUFA concentration in breast milk were identified in the literatures and shown in Table 1. These data are expressed as $w t \%$ of total fatty acids in breast milk. The overall data were split into five groups according to their region of investigation: Mainland of China, Asia (excluding Mainland of China), Europe, America and

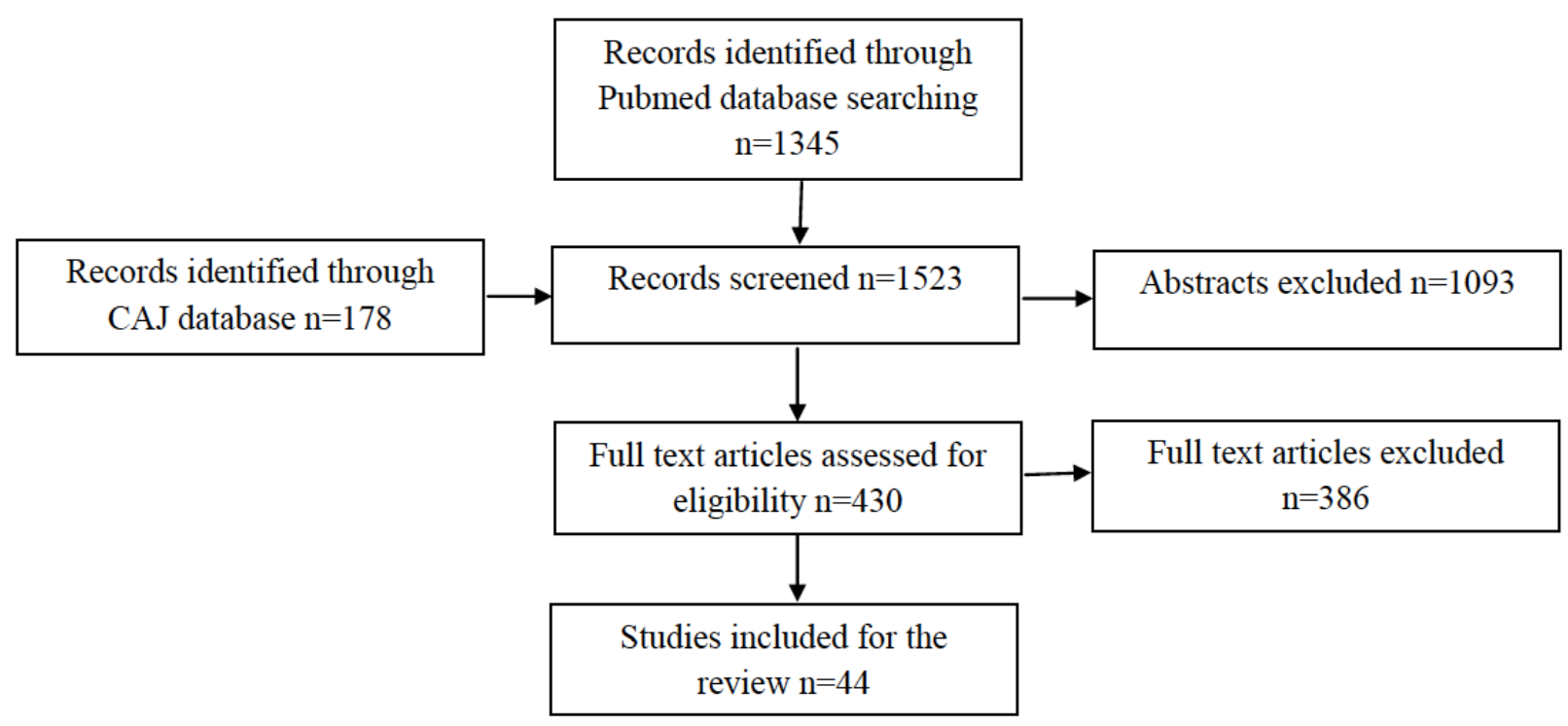

Figure 1: Flowchart of the search strategy used in this review. The number of relevant papers at each point is provided. 
Table 1: Studies Included in the Analysis ${ }^{1}$

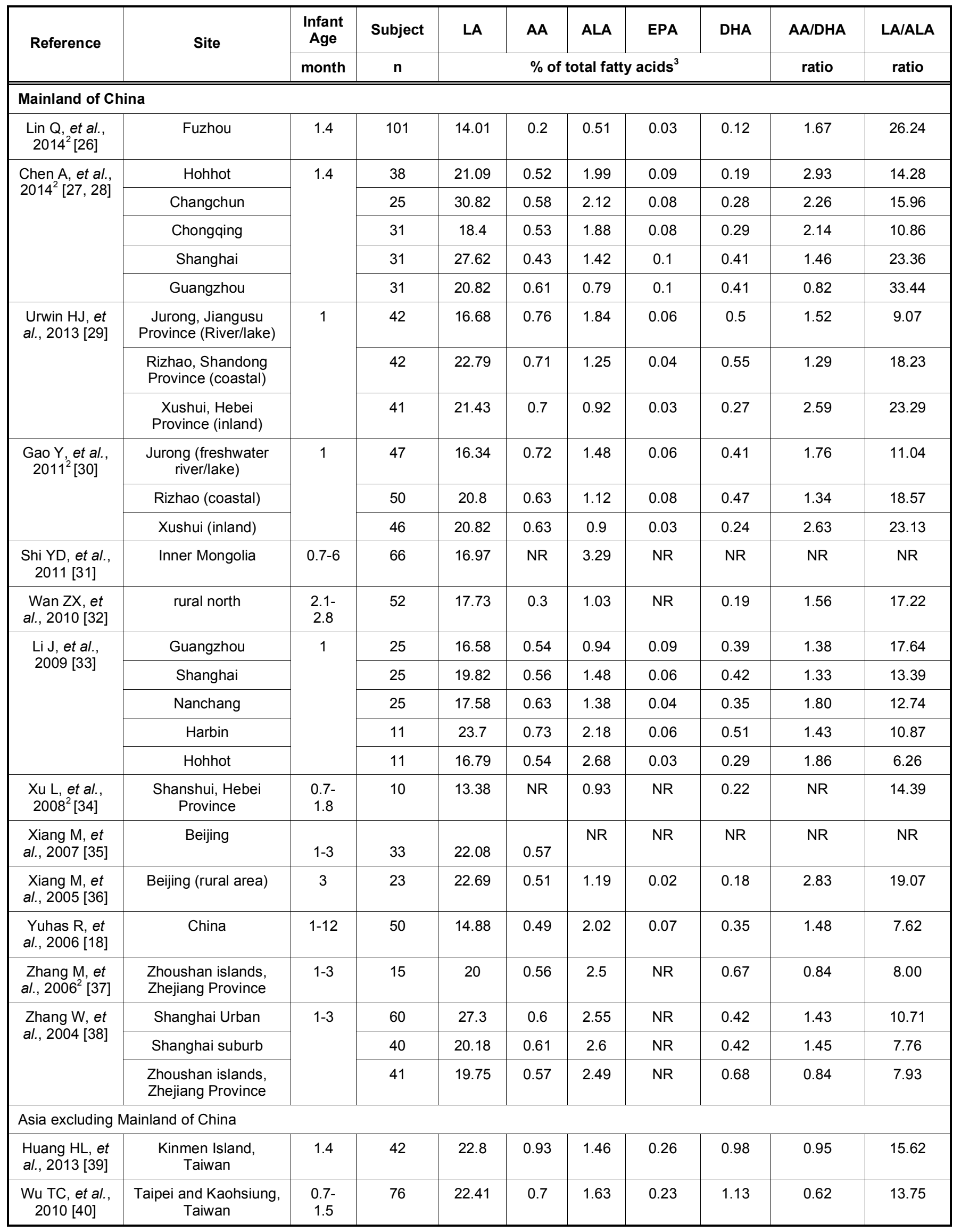




\begin{tabular}{|c|c|c|c|c|c|c|c|c|c|c|}
\hline $\begin{array}{l}\text { Thakkar SK et } \\
\text { al., } 2013 \text { [41] }\end{array}$ & Singapore & $1-2$ & 100 & 14.10 & 0.42 & 0.99 & 0.13 & 0.52 & 0.82 & 14.20 \\
\hline $\begin{array}{l}\text { Lee PS et al., } \\
2013 \text { [42] }\end{array}$ & Sri Lanka & $\begin{array}{l}1.4- \\
2.8\end{array}$ & 136 & 5.59 & 0.38 & 0.32 & 0.12 & 0.56 & 0.68 & 17.47 \\
\hline $\begin{array}{l}\text { Jirapinyo P, et } \\
\text { al., } 2008 \text { [44] }\end{array}$ & Thailand & 1 & 140 & 15.57 & 1.23 & 0.40 & 0.15 & 0.56 & 2.19 & 39.19 \\
\hline \multirow{2}{*}{$\begin{array}{l}\text { Golfetto I, et } \\
\text { al., } 2007 \text { [45] }\end{array}$} & Thailand & $1-2$ & 78 & 7.915 & 0.485 & 0.48 & 0.17 & 0.53 & 0.92 & 16.49 \\
\hline & Korea & 3 & 12 & 14.57 & 0.87 & 0.75 & 0.17 & 0.96 & 0.91 & 19.43 \\
\hline $\begin{array}{c}\text { Al-Tamer YY, } \\
\text { et al., } 2006 \\
{[47]}\end{array}$ & Iraq & $4-6$ & 65 & 10.80 & 0.22 & 0.21 & 0.08 & 0.12 & 1.83 & 52.27 \\
\hline $\begin{array}{l}\text { Bahrami G, et } \\
\text { al., } 2005 \text { [48] }\end{array}$ & Iran & $\begin{array}{l}1.5- \\
4.5\end{array}$ & 52 & 13.8 & 1.4 & 1.1 & 0.2 & NR & NR & 12.55 \\
\hline \multicolumn{11}{|l|}{ Europe } \\
\hline $\begin{array}{l}\text { Mihályi K, et } \\
\text { al., } 2015 \text { [49] }\end{array}$ & Hungary & 1.4 & 61 & 15.37 & 0.53 & 0.6 & 0.03 & 0.14 & 3.79 & 25.62 \\
\hline $\begin{array}{l}\text { Weiss GA, et } \\
\text { al., } 2013 \text { [50] }\end{array}$ & Switzerland & 1 & 7 & 18.43 & 1.48 & 1.82 & 0.07 & 0.56 & 2.64 & 10.13 \\
\hline $\begin{array}{l}\text { Mäkelä J, et } \\
\text { al., } 2012 \text { [54] }\end{array}$ & Finland & 3 & 49 & 11.1 & 0.39 & 2 & 0.18 & 0.46 & 0.85 & 5.55 \\
\hline $\begin{array}{c}\text { Martysiak- } \\
\text { Żurowska D, } \\
\text { et al., 2011 } \\
{[55]}\end{array}$ & Poland & $1-3$ & 93 & 10.37 & 0.41 & 1.20 & 0.06 & 0.27 & 1.53 & 8.67 \\
\hline $\begin{array}{c}\text { Moltó- } \\
\text { Puigmartí C, } \\
\text { et al., 2010 } \\
{[56]}\end{array}$ & Spain & 1 & 23 & 15.24 & 0.49 & 0.6 & 0.08 & 0.35 & 1.81 & 27 \\
\hline $\begin{array}{l}\text { Samur G, et } \\
\text { al., } 2009[57]\end{array}$ & Turkey & $2.8-4$ & 50 & 24.31 & 0.46 & 0.59 & NR & 0.15 & 3.07 & 41.20 \\
\hline $\begin{array}{c}\text { Scholtens S, } \\
\text { et al., 2009 } \\
{[58]}\end{array}$ & Netherlands & 3 & 244 & 15.07 & 0.37 & 1.02 & 0.05 & 0.20 & 1.90 & 14.83 \\
\hline $\begin{array}{c}\text { Rist L, et al., } \\
2007 \text { [59] }\end{array}$ & Netherland & 1 & 186 & 13.73 & 0.53 & 1.05 & NR & 0.42 & 1.26 & 13.08 \\
\hline $\begin{array}{l}\text { Jørgensen, } \\
\text { MH, et al., } \\
2006 \text { [60] }\end{array}$ & Denmark & $1-2$ & 33 & 10.71 & 0.515 & 1.4 & 0.13 & 0.46 & 1.12 & 7.65 \\
\hline
\end{tabular}


(Table 1). Continued.

\begin{tabular}{|c|c|c|c|c|c|c|c|c|c|c|}
\hline Reference & Site & $\begin{array}{l}\text { Infant } \\
\text { age }\end{array}$ & Subject & LA & AA & ALA & EPA & DHA & AA/DHA & LA/ALA \\
\hline $\begin{array}{l}\text { Yuhas R, et } \\
\text { al., } 2006 \text { [18] }\end{array}$ & United Kingdom & $1-12$ & 44 & 10.45 & 0.36 & 1.22 & 0.11 & 0.24 & 1.62 & 8.95 \\
\hline $\begin{array}{l}\text { Xiang M, et } \\
\text { al., } 2005[36]\end{array}$ & Sweden & 3 & 19 & 10.93 & 0.38 & 1.6 & 0.06 & 0.25 & 1.52 & 6.83 \\
\hline \multicolumn{11}{|l|}{ America } \\
\hline $\begin{array}{c}\text { Nishimura RY, } \\
\text { et al., } 2013 \\
{[61]}\end{array}$ & Brazil & $\begin{array}{l}1.2- \\
3.3\end{array}$ & 47 & 20.96 & 0.48 & 1.54 & 0.08 & 0.09 & 5.33 & 13.61 \\
\hline $\begin{array}{l}\text { Berenhauser } \\
\text { AC, et al., } \\
2012 \text { [62] }\end{array}$ & Brazil & $>0.5$ & 10 & 18.09 & 0.36 & NR & 0.01 & 0.03 & 12.00 & NR \\
\hline $\begin{array}{l}\text { Glew RH, et } \\
\text { al., } 2008 \text { [63] }\end{array}$ & US/New Mexico & $1-6$ & 29 & NR & 0.44 & 1.23 & 0.08 & 0.11 & 4.00 & NR \\
\hline $\begin{array}{l}\text { Friesen } \mathrm{R} \text {, et } \\
\text { al., } 2006 \text { [64] }\end{array}$ & Canada & 1 & 87 & 12.87 & 0.4 & 1.4 & 0.1 & 0.27 & 1.50 & 9.19 \\
\hline \multirow{4}{*}{$\begin{array}{l}\text { Yuhas R, et } \\
\text { al., } 2006 \text { [18] }\end{array}$} & Canada & \multirow[t]{4}{*}{$1-12$} & 48 & 11.48 & 0.37 & 1.22 & 0.08 & 0.17 & 2.35 & 9.89 \\
\hline & Chile & & 50 & 17.75 & 0.42 & 1.14 & 0.09 & 0.43 & 1.04 & 17.85 \\
\hline & Mexico & & 46 & 16.05 & 0.42 & 1.05 & 0.07 & 0.26 & 2.01 & 16.91 \\
\hline & United States & & 49 & 14.78 & 0.45 & 1.05 & 0.07 & 0.17 & 3.16 & 15.44 \\
\hline $\begin{array}{l}\text { Torres AG, et } \\
\text { al., } 2006 \text { [65] }\end{array}$ & Brazil & $1-4$ & 33 & 16.6 & 0.47 & 1.16 & 0.071 & 0.22 & 2.14 & 14.31 \\
\hline $\begin{array}{l}\text { Marin MC, et } \\
\text { al., } 2005 \text { [66] }\end{array}$ & Argentina & $1-4$ & 21 & 16.61 & 0.45 & 0.47 & 0.09 & 0.13 & 3.46 & 35.34 \\
\hline $\begin{array}{l}\text { Bopp M, et al., } \\
2005 \text { [67] }\end{array}$ & US & $\begin{array}{l}2.3- \\
3.3\end{array}$ & 26 & 15.83 & 0.40 & 1.09 & 0.35 & 0.32 & 1.23 & 14.59 \\
\hline \multicolumn{11}{|l|}{ Africa } \\
\hline $\begin{array}{l}\text { Nyuar KB, et } \\
\text { al., } 2013 \text { [68] }\end{array}$ & Sudan & $0.8-1$ & 32 & 14.7 & 0.6 & 0.28 & 0.04 & 0.1 & 6.00 & 52.50 \\
\hline $\begin{array}{l}\text { Kuipers RS, et } \\
\text { al., } 2012 \text { [69] }\end{array}$ & $\begin{array}{c}\text { Tanzania (sub- } \\
\text { Saharan population) }\end{array}$ & $0.5-2$ & 34 & 15.8 & 0.55 & 0.52 & 0.09 & 0.53 & 1.04 & 30.38 \\
\hline
\end{tabular}

${ }^{1}$ LA, Linoleic acid; AA, Arachidonic acid; ALA, Alpha- linolenic acid; EPA, Eicosapentaenoic acid; DHA, Docosahexaenoic acid. NR, not reported. ${ }^{2}$ Articles in Chinese.

${ }^{3}$ By weight.

Table 2: Essential Fatty Acid Concentrations in Different Regions ${ }^{1}$

\begin{tabular}{|c|c|c|c|c|}
\hline Group & $\mathbf{n}^{3}$ & $\mathbf{N}^{4}$ & LA & ALA \\
\hline \hline China & 1012 & 13 & $20.04 \pm 4.12$ & $1.67 \pm 0.72$ \\
\hline Asia & 1052 & 11 & $14.06 \pm 5.36^{*}$ & $1.13 \pm 0.93^{*}$ \\
\hline Europe & 1239 & 14 & $14.10 \pm 3.96^{*}$ & $1.12 \pm 0.54^{*}$ \\
\hline America & 446 & 8 & $16.10 \pm 2.68^{*}$ & $1.14 \pm 0.28$ \\
\hline Africa & 66 & 2 & $15.25 \pm 0.78$ & $0.40 \pm 0.17^{*}$ \\
\hline
\end{tabular}

${ }^{1}$ Fatty acid concentrations are expressed as mean \pm Standard Deviation \%wt of total fatty acids.

*Significant difference compared to Chinese Group according to Dunnett's test $(p<0.05)$.

LA, Linoleic acid; ALA, Alpha- linolenic acid.

${ }^{2}$ Asia excluding Mainland of China.

${ }^{3} \mathrm{n}$ : Subject numbers.

${ }^{4} \mathrm{~N}$ : Reference numbers. 
Table 3: Other Long-Chain Unsaturated Fatty Acid Concentrations in Different Regions ${ }^{1}$

\begin{tabular}{|c|c|c|c|c|c|c|}
\hline Group & $\mathbf{n}^{3}$ & $\mathbf{N}^{4}$ & AA & EPA & DHA & AA/DHA \\
\hline \hline China & 1012 & 13 & $0.57 \pm 0.13$ & $0.06 \pm 0.03$ & $0.37 \pm 0.15$ & $1.69 \pm 0.60$ \\
\hline Asia $^{2}$ & 1052 & 11 & $0.65 \pm 0.36$ & $0.21 \pm 0.13^{*}$ & $0.67 \pm 0.32^{*}$ & $1.12 \pm 0.69$ \\
\hline Europe & 1239 & 14 & $0.56 \pm 0.31$ & $0.09 \pm 0.04$ & $0.34 \pm 0.14$ & $1.89 \pm 0.82$ \\
\hline America & 446 & 8 & $0.42 \pm 0.39$ & $0.10 \pm 0.09$ & $0.20 \pm 0.11$ & $3.47 \pm 3.10^{*}$ \\
\hline Africa & 66 & 2 & $0.58 \pm 0.04$ & $0.07 \pm 0.04$ & $0.32 \pm 0.30$ & $3.52 \pm 3.51$ \\
\hline Mean worldwide $^{5}$ & & $0.47 \pm 0.13$ & & $0.32 \pm 0.22$ \\
\hline
\end{tabular}

${ }^{1}$ Fatty acid concentrations are expressed as mean \pm Standard Deviation \%wt of total fatty acids.

*Significant difference compared to Chinese Group according to Dunnett's test $(p<0.05)$.

AA, Arachidonic acid; EPA, Eicosapentaenoic acid; DHA, Docosahexaenoic acid.

${ }^{2}$ Asia excluding Mainland of China

${ }^{3} \mathrm{n}$ : Subject numbers

${ }^{4} \mathrm{~N}$ : Reference numbers

${ }^{5}$ The mean of AA and DHA concentrations in human milk worldwide [12]

Africa. The mean value and standard deviation of the fatty acid concentrations in breast milk were calculated for different groups and shown in Tables 2 \& 3.

The results showed that Chinese mothers had significantly higher LA level in their breast milk than their counterparts in America, Europe and other Asian regions $(p<0.05$; Table 2). Chinese mothers also had significantly higher ALA level in their breast milk than their counterparts in Africa, Europe and other Asian regions ( $p<0.05$; Table 2). Chinese mothers had significantly lower LA/ALA ratio than African mothers ( $p$ $<0.05$; Table 2).

There were no significant differences in the AA level in the breast milk among different groups. Chinese mothers had significantly lower EPA and DHA levels in the breast milk than other Asian mothers $(p<0.05$; Table 3). The regions with high EPA and DHA levels in the breast milk in the Asian group (excluding Mainland of China) were Taiwan, Korea, Japan and the Philippines (Table 1). Chinese mothers had significantly lower AA/DHA ratio in their breast milk than American mothers $(p<0.05$; Table 3$)$ due to the relatively low concentration of DHA in the breast milk of the latter.

\section{DISCUSSION}

The LC-PUFAs are essential to infant growth and development during early life and are considered to affect disease risk in later life [13]. It has been shown that prenatal LC-PUFAs availability could affect the cardiometabolic disease risk at childhood [13]. There are only a few studies on the LC-PUFA levels in breast milk of Chinese mothers with large sample size. A systematic review on the DHA and AA concentrations in human breast milk worldwide was conducted in 2007 [12]. 65 studies were included in that review, and among them only 3 studies mostly from Beijing representing data from China. Thus, there is a need to review the recent studies on LC-PUFA levels in breast milk of Chinese mothers since 2007. This study reviewed and analyzed data on LC-PUFA concentrations in human mature milk from 1-6 months in articles published in the last 10 years (from 20052015). The results showed that Chinese mothers had significantly higher LA and ALA levels in their breast milk than their counterparts in Europe and other Asian regions $(p<0.05$; Table 2$)$. On the other hand, Chinese mothers had significantly lower EPA and DHA level in the breast milk than other Asian mothers $(p<$ 0.05; Table 3).

There are three sources of fatty acids in human breast milk: diet, mammary gland synthesis and tissue mobilization from maternal storage [14]. It is generally believed that human breast milk fatty acid composition worldwide is subjected to inter-individual biological variation mainly due to different maternal diets [15-17]. This study showed that Chinese mothers had significant higher levels of LA and ALA in their breast milk than other Asian and European mothers $(p<0.05$; Table 2). The essential fatty acids LA and ALA cannot be synthesized by the human body and therefore must be obtained from dietary sources. It is reported that about $30 \%$ of LA in milk is directly transferred from the maternal diet, and LA level in human breast milk is significantly correlated with the maternal dietary intake of LA $[18,19]$. Mothers from some cities in China such as Changchun, Beijing and Shanghai had significant higher LA Level. The high level of LA concentrations in Chinese may be related to the high usage of vegetable 
oil such as soybean oil, corn oil, sunflower seed oil and peanut oil which are high in LA. There are regional differences in the types of vegetable oil consumed by the Chinese populations. Northern Chinese prefer soybean oil which contains higher levels of ALA. Northwestern Chinese and people living in the Yangzi River region prefer canola oil and rapeseed oil which are also high in ALA. Southern Chinese and people from Shandong Province prefer peanut oil which is low in ALA, but they consumed a lot of seafood, which provides abundant ALA, as they live near the sea. There were no significant differences in the ratio of LA/ALA between Chinese mothers and mothers from other regions except those in Africa. The recommended ratio of LA/ALA is $5-15$ by the European Society for Pediatric Gastroenterology and Nutrition (ESPGAN). Most mother except those in Africa generally meet this criterion.

LC-PUFAs, especially AA and DHA, are the main components of the phospholipids in the brain and retina. These LC-PUFAs are in great demand by the infant during the $3^{\text {rd }}$ trimester of pregnancy and the first 2 years postpartum which is the rapid developmental period for the brain [12]. The DHA concentration in breast milk is greatly affected by the maternal diet, whereas the AA contents are less affected by it [12, 20]. This study showed that there were no significant differences in the AA level in the breast milk among the different groups but Chinese mothers had significantly lower DHA level in their breast milk than other Asian mothers $(p<0.05$; Table 3$)$. There were also no significant differences in the AA/DHA ration in the breast milk of Chinese mothers and that of other Asian mothers. The mean AA and DHA concentrations in the breast milk of Chinese mothers $(0.57 \pm 0.13 \%$, $0.37 \pm 0.15 \%)$ is slightly higher than mean worldwide $(0.47 \pm 0.13 \%, 0.32 \pm 0.22 \%)$ [12]. Mothers from some island countries and regions such as Japan (0.99\%), Korean $(0.96 \%)$ and Taiwan $(0.98 \%, 1.13 \%)$ accounted for the high levels of DHA concentrations in the breast milk of Asian mothers (Table 1). Chinese mothers had significantly lower AA/DHA ratio in their breast milk than American mothers $(p<0.05$; Table 3$)$ due to the lower DHA level in the breast milk of the latter. Women from Brazil and the US had lower levels of DHA in breast milk. Maternal seafood consumption may increase the DHA level in breast milk and may show beneficial effect on the neurodevelopmental outcomes in childhood [21, 22]. Chinese mothers living in coastal cities such as Rizhao, Zhoushan Islands, and Shanghai $(0.51 \%, \quad 0.68 \%$ and $0.42 \%)$ had higher DHA concentrations in breast milk than those living in inland cities such as Hohhot and Xushui $(0.03 \%$ and $0.03 \%)$. This suggests lactating women from inland cities should have more fish intake or n-3 fatty acid intake from supplements or other food sources such as algae to increase the DHA levels in their breast milk.

The FAO report in 2010 indicates that DHA is synthesized limitedly in infants from 0-6 months old, and DHA is regarded as a conditional essential fatty acid for infants [23]. The average DHA concentration worldwide from the systematic review in 2007 was $0.42 \%$ [12], which is equivalent to $84 \mathrm{mg} / \mathrm{d}$. The recommended DHA intake by 0-6 month infants is 58 $\mathrm{mg}-104 \mathrm{mg} / \mathrm{d}$ by the same report [23]. The adequate intake (Al) of DHA in Chinese is $100 \mathrm{mg} / \mathrm{d}$ for $0-6$ month infants [24], which is consistent with the recommendation by EFSA2010 [25]. From the literature review [24], we assume the fat concentration in the breast milk is $36.5 \mathrm{~g} / \mathrm{L}$, and about $96 \%$ of the total fat is fatty acids. The average daily milk secretion by human is around $750 \mathrm{~mL}$ from $0-6$ months. The mean DHA level in the breast milk of Chinese mothers in this study is $0.37 \%$, which is equivalent to $97 \mathrm{mg} / \mathrm{d}(36.5 \mathrm{~g} / \mathrm{L} \times$ $0.75 \mathrm{~L} / \mathrm{d} \times 96 \% \times 0.37 \%=0.097 \mathrm{~g} / \mathrm{d}$ ). Thus, the mean DHA level in the breast milk of Chinese mothers meets the Chinese, FAO and EFSA recommended intake of DHA for 0-6 month infants.

Chinese mothers had significantly lower EPA level in their breast milk than mothers from other regions in Asia $(0.06 \pm 0.03 \%$ vs. $0.21 \pm 0.13 \%, p<0.05$; Table 3 ). Japanese $(0.26 \%)$, Taiwanese $(0.25 \%)$ and Indian $(0.59 \%)$ mothers had higher EPA level in their breast milk. Their high fish consumption may correlate with their high levels of EPA in the breast milk. However, the low level of EPA in the breast milk of Chinese mothers even in some coastal cities may suggest other contributing factors such as genetics.

Maternal diet structure may have great impact on the concentrations of LC-PUFA in the breast milk which in turn may affect the development of infants with longterm consequences [22]. We reviewed studies on the LC-PUFA concentrations in the breast milk of mothers in China and other regions published in the last 10 years. Generally, Chinese mothers tended to have higher levels of essential fatty acids (LA and ALA) in the breast milk than mothers in other regions. Although Chinese mothers have significantly lower EPA and DHA levels than those Asian mothers from island regions, the DHA level in the breast milk of Chinese mothers still meets the Chinese and international 
recommended DHA intake for infants. This study may serve as a reference for further study on LC-PUFA in the breast milk of Chinese mothers.

\section{REFERENCES}

[1] Venegas-Caleron M, Sayanova O, Napier JA. An alternative to fish oils: Metabolic engineering of oil-seed crops to produce omega-3 long chain polyunsaturated fatty acids. Prog Lipid Res 2010; 49: 108-19. http://dx.doi.org/10.1016/j.plipres.2009.10.001

[2] Hageman JH, Hooyenga $P$, Diersen-Schade DA, Scalabrin DM, Wichers HJ, Birch EE. The impact of dietary long-chain polyunsaturated fatty acids on respiratory illness in infants and children. Curr Allergy Asthma Rep 2012; 12: 564-73. http://dx.doi.org/10.1007/s11882-012-0304-1

[3] Peng $Y$, Zhou T, Wang Q, et al. Fatty acid composition of diet, cord blood and breast milk in Chinese mothers with different dietary habits. Prostaglandins Leukot Essent Fatty Acids 2009; 81: 325-30. http://dx.doi.org/10.1016/j.plefa.2009.07.004

[4] Calder PC. Omega-3 polyunsaturated fatty acids and inflammatory processes: nutrition or pharmacology? $\mathrm{Br} \mathrm{J}$ Clin Pharmacol 2013; 75: 645-62.

[5] Gibson RA, Muhlhausler B, Makrides M. Conversion of linoleic acid and alpha-linolenic acid to long-chain polyunsaturated fatty acids (LCPUFAs), with a focus on pregnancy, lactation and the first 2 years of life. Matern Child Nutr 2011; 7 Suppl 2: 17-26. http://dx.doi.org/10.1111/j.1740-8709.2011.00299.x

[6] Burdge GC, Calder PC. Dietary alpha-linolenic acid and health-related outcomes: a metabolic perspective. Nutr Res Rev 2006; 19: 26-52.

http://dx.doi.org/10.1079/NRR2005113

[7] Clouard C, Gerrits WJ, van Kerkhof I, Smink W, Bolhuis JE. Dietary linoleic and alpha-linolenic acids affect anxietyrelated responses and exploratory activity in growing pigs. J Nutr 2015; 145: 358-64.

http://dx.doi.org/10.3945/jn.114.199448

[8] Feng Y, Ding Y, Liu J, Tian Y, Yang Y, Guan S, Zhang C. Effects of dietary omega-3/omega- 6 fatty acid ratios on reproduction in the young breeder rooster. BMC Vet Res 2015; $11: 73$. http://dx.doi.org/10.1186/s12917-015-0394-9

[9] Agostoni C, Braegger C, Decsi T, et al. Breast-feeding: A commentary by the ESPGHAN Committee on Nutrition. J Pediatr Gastroenterol Nutr 2009; 49: 112-25. http://dx.doi.org/10.1097/MPG.0b013e31819f1e05

[10] Koletzko B, Boey CC, Campoy C, et al. Current information and Asian perspectives on long-chain polyunsaturated fatty acids in pregnancy, lactation, and infancy: systematic review and practice recommendations from an early nutrition academy workshop. Ann Nutr Metab 2014; 65: 49-80. http://dx.doi.org/10.1159/000365767

[11] Zhang J, Wang C, Gao Y, et al. Different intakes of n-3 fatty acids among pregnant women in 3 regions of China with contrasting dietary patterns are reflected in maternal but not in umbilical erythrocyte phosphatidylcholine fatty acid composition. Nutr Res 2013; 33: 613-21. http://dx.doi.org/10.1016/j.nutres.2013.05.009

[12] Brenna JT, Varamini B, Jensen RG, Diersen-Schade DA, Boettcher JA, Arterburn LM. Docosahexaenoic and arachidonic acid concentrations in human breast milk worldwide. Am J Clin Nutr 2007; 85: 1457-64.

[13] Jochems SH, Gielen M, Rump P, Hornstra G, Zeegers MP. Potential programming of selected cardiometabolic risk factors at childhood by maternal polyunsaturated fatty acid availability in the MEFAB cohort. Prostaglandins Leukot Essent Fatty Acids 2015; 100: 21-7.

http://dx.doi.org/10.1016/j.plefa.2015.06.001

[14] Jensen RG. The lipids in human milk. Prog Lipid Res 1996; 35: 53-92.

http://dx.doi.org/10.1016/0163-7827(95)00010-0

[15] Rocquelin G, Tapsoba S, Kiffer J, Eymard-Duvernay $S$. Human milk fatty acids and growth of infants in Brazzaville (The Congo) and Ouagadougou (Burkina Faso). Public Health Nutr 2003; 6: 241-8.

http://dx.doi.org/10.1079/PHN2002420

[16] Bokor S, Koletzko B, Decsi T. Systematic review of fatty acid composition of human milk from mothers of preterm compared to full-term infants. Ann Nutr Metab 2007; 51: 5506. http://dx.doi.org/10.1159/000114209

[17] Neville MC, Picciano MF. Regulation of milk lipid secretion and composition. Annu Rev Nutr 1997; 17: 159-83. http://dx.doi.org/10.1146/annurev.nutr.17.1.159

[18] Yuhas R, Pramuk K, Lien EL. Human milk fatty acid composition from nine countries varies most in DHA. Lipids 2006; 41: 851-8.

http://dx.doi.org/10.1007/s11745-006-5040-7

[19] Demmelmair H, Baumheuer M, Koletzko B, Dokoupil K, Krat G. Metabolism of U13C-labeled linoleic acid in lactating women. J Lipid Res 1998; 39: 1389-96.

[20] Demmelmair H, Baumheuer M, Koletzko B, Dokoupil K, Kratl G. Investigation of long-chain polyunsaturated fatty acid metabolism in lactating women by means of stable isotope techniques. Adv Exp Med Biol 2001; 501: 169-77. http://dx.doi.org/10.1007/978-1-4615-1371-1_22

[21] Hibbeln JR, Davis JM, Steer C, Emmett P, Rogers I, Williams $\mathrm{C}$, Golding J. Maternal seafood consumption in pregnancy and neurodevelopmental outcomes in childhood (ALSPAC study): an observational cohort study. Lancet 2007; 369: 578-85.

http://dx.doi.org/10.1016/S0140-6736(07)60277-3

[22] Innis SM. Impact of maternal diet on human milk composition and neurological development of infants. Am J Clin Nutr 2014; 99: 734s-41s.

http://dx.doi.org/10.3945/ajcn.113.072595

[23] Food and Agriculture Orgnization of the United Nations: Fats and Fatty Acids in Human Nutrition: Report of a Joint FAO/WHO Expert Consultation 2010; Rome, FAO.

[24] Chinese nutrition Association: Chinese dietary reference intakes. 2013.

[25] EFSA. Scienrific opinion on Dietary Reference Values for fats, including saturated fatty acids, polyunsaturated fatty acids, monounsaturated fatty acids, trans fatty acids, and cholesterol. EFSA Journal 2010; 8: 1461.

[26] Lin Q, Li G, Ge P, Zu R. Fatty acid compostition in breast milk and its influencing factors. Chin Prev Med 2014; 15: 663-7.

[27] Chen A, Zhang W, Jiang M, He J, Wu S, Huang Q, Zheng M. Fatty acid compostions of human breast milk in five regions of China. J Clin Pediatr 2014; 32: 48-54.

[28] Zhang W, Chen A, Jiang M, He J, Wu S, Huang Q, Zheng M. Fatty acid compostion of human breast milk in Shanghai and Chongqing of China. J Clin Pediatr 2011; 29: 201-7.

[29] Urwin HJ, Zhang J, Gao Y, et al. Immune factors and fatty acid composition in human milk from river/lake, coastal and inland regions of China. Br J Nutr 2013; 109: 1949-61. http://dx.doi.org/10.1017/S0007114512004084

[30] Gao Y, Zhang J, Wang C, Li L, Man Q, Song P. [Fatty acid composition of mature human milk in three regions of $\mathrm{China]}$ Wei Sheng Yan Jiu 2011; 40: 731-4. 
[31] Shi YD, Sun GQ, Zhang ZG, Deng X, Kang XH, Liu ZD, Ma $\mathrm{Y}$, Sheng $\mathrm{QH}$. The chemical composition of human milk from Inner Mongolia of China. Food Chem 2011; 127: 1193-8. http://dx.doi.org/10.1016/j.foodchem.2011.01.123

[32] Wan ZX, Wang XL, Xu L, Geng Q, Zhang Y. Lipid content and fatty acids composition of mature human milk in rural North China. Br J Nutr 2010; 103: 913-6. http://dx.doi.org/10.1017/S0007114509992455

[33] Li J, Fan Y, Zhang Z, Yu H, An Y, Kramer JK, Deng Z. Evaluating the trans fatty acid, CLA, PUFA and erucic acid diversity in human milk from five regions in China. Lipids 2009; 44: 257-71. http://dx.doi.org/10.1007/s11745-009-3282-x

[34] Xu L, Du Y, Ma J, Sheng Q. The survey of the content of human milk amino acid and fatty acid from a certain district in Hebei province. Food Science and Technology 2008: 231-3.

[35] Xiang M, Harbige LS, Zetterstrom R. Breast milk levels of zinc and omega- 6 polyunsaturated fatty acids and growth of healthy Chinese infants. Acta Paediatr 2007; 96: 387-90. http://dx.doi.org/10.1111/j.1651-2227.2006.00140.x

[36] Xiang M, Harbige LS, Zetterstrom R. Long-chain polyunsaturated fatty acids in Chinese and Swedish mothers: diet, breast milk and infant growth. Acta Paediatr 2005; 94: 1543-9.

http://dx.doi.org/10.1080/08035250500251601

[37] Zhang M, Huang L. The analysis of DHA and AA contents in the breast milk in Zhoushan District. Chinese Journal of Child Health Care 2006; 14: 514-5.

[38] Zhang W, Wu S, Qian J, Yang H, Zhuang M, Cao L, Wu Y, Gao X. Comparison of contents of polyunsaturated fatty acids of breast milk among different regions of China and between colostrums and mature milk. Chinese Journal of Clinical Rehabilitation 2004; 8: 2389-91.

[39] Huang HL, Chuang LT, Li HH, Lin CP, Glew RH. Docosahexaenoic acid in maternal and neonatal plasma phospholipids and milk lipids of Taiwanese women in Kinmen: fatty acid composition of maternal blood, neonatal blood and breast milk. Lipids Health Dis 2013; 12: 27.

http://dx.doi.org/10.1186/1476-511X-12-27

[40] Wu TC, Lau BH, Chen PH, Wu LT, Tang RB. Fatty acid composition of Taiwanese human milk. J Chin Med Assoc 2010; 73: 581-8.

http://dx.doi.org/10.1016/S1726-4901(10)70127-1

[41] Thakkar SK, Giuffrida F, Cristina CH, De Castro CA, Mukherjee R, Tran LA, Steenhout P, Lee le Y, Destaillats F. Dynamics of human milk nutrient composition of women from Singapore with a special focus on lipids. Am J Hum Biol 2013; 25: 770-9.

http://dx.doi.org/10.1002/ajhb.22446

[42] Lee PS, Wickramasinghe VP, Lamabadusuriya SP, Duncan AW, Wainscott G, Weeraman JD, Wijekoon AS, Wong KH. Breast milk DHA levels in Sri Lankan mothers vary significantly in three locations that have different access to dietary fish. Ceylon Med J 2013; 58: 51-5.

http://dx.doi.org/10.4038/cmj.v58i2.5679

[43] Roy S, Ghosh S, Dhar P, Ghosh M. Studies on the fluidity of milk lipids of mothers from three socioeconomic groups of West Bengal, India. J Trop Pediatr 2013; 59: 407-12. http://dx.doi.org/10.1093/tropej/fmt040

[44] Jirapinyo $P$, Densupsoontorn $N$, Wiraboonchai D, Vissavavejam $U$, Tangtrakulvachira $T$, Chungsomprasong $P$, Thamonsiri N, Wongarn R. Fatty acid composition in breast milk from 4 regions of Thailand. J Med Assoc Thai 2008; 91: 1833-7.

[45] Golfetto I, McGready R, Ghebremeskel K, Min Y, Dubowitz L, Nosten F, Drury P, Simpson JA, Arunjerdja R, Crawford MA. Fatty acid composition of milk of refugee Karen and urban Korean mothers. Is the level of DHA in breast milk of
Western women compromised by high intake of saturated fat and linoleic acid? Nutr Health 2007; 18: 319-32.

http://dx.doi.org/10.1177/026010600701800402

[46] Saphier O, Blumenfeld J, Silberstein T, Tzor T, Burg A. Fatty acid composition of breastmilk of Israeli mothers. Indian Pediatr 2013; 50: 1044-6.

http://dx.doi.org/10.1007/s13312-013-0277-8

[47] Al-Tamer YY, Mahmood AA. The influence of Iraqi mothers' socioeconomic status on their milk-lipid content. Eur J Clin Nutr 2006; 60: 1400-5.

http://dx.doi.org/10.1038/sj.ejcn. 1602470

[48] Bahrami G, Rahimi Z. Fatty acid composition of human milk in Western Iran. Eur J Clin Nutr 2005; 59: 494-7. http://dx.doi.org/10.1038/sj.ejcn.1602099

[49] Mihályi K, Györei E, Szabó É, Marosvölgyi T, Lohner S, Decsi T. Contribution of $n-3$ long-chain polyunsaturated fatty acids to human milk is still low in Hungarian mothers. Eur $\mathrm{J}$ Pediatr 2015; 174: 393-8. http://dx.doi.org/10.1007/s00431-014-2411-6

[50] Weiss GA, Troxler H, Klinke G, Rogler D, Braegger C, Hersberger M. High levels of anti-inflammatory and proresolving lipid mediators lipoxins and resolvins and declining docosahexaenoic acid levels in human milk during the first month of lactation. Lipids Health Dis 2013; 12: 89.

http://dx.doi.org/10.1186/1476-511X-12-89

[51] Pedersen L, Lauritzen L, Brasholt M, Buhl T, Bisgaard $H$. Polyunsaturated fatty acid content of mother's milk is associated with childhood body composition. Pediatr Res 2012; 72: 631-6. http://dx.doi.org/10.1038/pr.2012.127

[52] Antonakou A, Skenderi KP, Chiou A, Anastasiou CA, Bakoula C, Matalas AL. Breast milk fat concentration and fatty acid pattern during the first six months in exclusively breastfeeding Greek women. Eur J Nutr 2013; 52: 963-73. http://dx.doi.org/10.1007/s00394-012-0403-8

[53] Urwin HJ, Miles EA, Noakes PS, Kremmyda LS, Vlachava M, Diaper ND, Perez-Cano FJ, Godfrey KM, Calder PC, Yaqoob $P$. Salmon consumption during pregnancy alters fatty acid composition and secretory $\lg A$ concentration in human breast milk. J Nutr 2012; 142: 1603-10.

http://dx.doi.org/10.3945/jn.112.160804

[54] Mäkelä J, Linderborg K, Niinikoski H, Yang B, Lagström H. Breast milk fatty acid composition differs between overweight and normal weight women: the STEPS Study. Eur J Nutr 2013; 52: 727-35.

http://dx.doi.org/10.1007/s00394-012-0378-5

[55] Martysiak-Żurowska D, Zóralska K, Zagierski M, SzlagtysSidorkiewicz A. [Fatty acid composition in breast milk of women from Gdansk and the surrounding district in the course of lactation]. Med Wieku Rozwoj 2011; 15: 167-77.

[56] Moltó-Puigmartí C, Castellote Al, Carbonell-Estrany X, López-Sabater MC. Differences in fat content and fatty acid proportions among colostrum, transitional, and mature milk from women delivering very preterm, preterm, and term infants. Clin Nutr 2011; 30: 116-23. http://dx.doi.org/10.1016/i.clnu.2010.07.013

[57] Samur G, Topcu A, Turan S. Trans fatty acids and fatty acid composition of mature breast milk in turkish women and their association with maternal diet's. Lipids 2009; 44: 405-13. http://dx.doi.org/10.1007/s11745-009-3293-7

[58] Scholtens S, Wijga AH, Smit HA, Brunekreef B, de Jongste JC, Gerritsen J, Seidell JC. Long-chain polyunsaturated fatty acids in breast milk and early weight gain in breast-fed infants. Br J Nutr 2009; 101: 116-21. http://dx.doi.org/10.1017/S0007114508993521

[59] Rist L, Mueller A, Barthel C, Snijders B, Jansen M, SimoesWust AP, Huber M, Kummeling I, von Mandach U, Steinhart $\mathrm{H}$, Thijs $\mathrm{C}$. Influence of organic diet on the amount of 
conjugated linoleic acids in breast milk of lactating women in the Netherlands. Br J Nutr 2007; 97: 735-43.

http://dx.doi.org/10.1017/S0007114507433074

[60] Jørgensen $\mathrm{MH}$, Nielsen PK, Michaelsen KF, Lund $\mathrm{P}$, Lauritzen $\mathrm{L}$. The composition of polyunsaturated fatty acids in erythrocytes of lactating mothers and their infants. Matern Child Nutr 2006; 2: 29-39.

http://dx.doi.org/10.1111/j.1740-8709.2006.00039.x

[61] Nishimura RY, Castro GS, Jordão AA, Jr., Sartorelli DS. Breast milk fatty acid composition of women living far from the coastal area in Brazil. J Pediatr (Rio J) 2013; 89: 263-8. http://dx.doi.org/10.1016/j.jped.2012.11.007

[62] Berenhauser AC, Pinheiro do Prado AC, da Silva RC, Gioielli LA, Block JM. Fatty acid composition in preterm and term breast milk. Int J Food Sci Nutr 2012; 63: 318-25. http://dx.doi.org/10.3109/09637486.2011.627843

[63] Glew RH, Wold RS, Herbein JH, Wark WA, Martinez MA, Vanderjagt DJ. Low docosahexaenoic acid in the diet and milk of women in New Mexico. J Am Diet Assoc 2008; 108: 1693-9. http://dx.doi.org/10.1016/j.jada.2008.07.006

[64] Friesen R, Innis SM. Trans fatty acids in human milk in Canada declined with the introduction of trans fat food labeling. J Nutr 2006; 136: 2558-61.

[65] Torres AG, Ney JG, Meneses F, Trugo NM. Polyunsaturated fatty acids and conjugated linoleic acid isomers in breast milk are associated with plasma non-esterified and erythrocyte membrane fatty acid composition in lactating women. $\mathrm{Br} \mathrm{J}$ Nutr 2006; 95: 517-24. http://dx.doi.org/10.1079/BJN20051645

[66] Marin MC, Sanjurjo A, Rodrigo MA, de Alaniz MJ. Long-chain polyunsaturated fatty acids in breast milk in La Plata, Argentina: relationship with maternal nutritional status. Prostaglandins Leukot Essent Fatty Acids 2005; 73: 355-60. http://dx.doi.org/10.1016/j.plefa.2005.07.005

[67] Bopp M, Lovelady C, Hunter C, Kinsella T. Maternal diet and exercise: effects on long-chain polyunsaturated fatty acid concentrations in breast milk. J Am Diet Assoc 2005; 105: 1098-103.

http://dx.doi.org/10.1016/j.jada.2005.04.004

[68] Nyuar KB, Min Y, Dawood M, Abukashawa S, Daak A, Ghebremeskel K. Regular consumption of Nile river fish could ameliorate the low milk DHA of Southern Sudanese women living in Khartoum City area. Prostaglandins Leukot Essent Fatty Acids 2013; 89: 65-9. http://dx.doi.org/10.1016/j.plefa.2013.04.007

[69] Kuipers RS, Luxwolda MF, Dijck-Brouwer DA, Muskiet FA. Fatty acid compositions of preterm and term colostrum, transitional and mature milks in a sub-Saharan population with high fish intakes. Prostaglandins Leukot Essent Fatty Acids 2012; 86: 201-7.

http://dx.doi.org/10.1016/j.plefa.2012.02.006

Received on 30-09-2015

Accepted on 02-11-2015

Published on 11-12-2015

http://dx.doi.org/10.6000/1929-4247.2015.04.04.5

(C) 2015 Li et al.; Licensee Lifescience Global.

This is an open access article licensed under the terms of the Creative Commons Attribution Non-Commercial License (http://creativecommons.org/licenses/by-nc/3.0/) which permits unrestricted, non-commercial use, distribution and reproduction in any medium, provided the work is properly cited. 